\title{
ESTIMASI NILAI TUKAR RUPIAH PASKA KRISIS: \\ Pendekatan Model Komposit
}

\section{Jardine Ariena Husman}

\begin{abstract}
This paper examines the factors that determined the Indonesian rupiah against US dollar nominal exchange rate post crisis period. The effect of the oil prices and the interaction of supply and demand in the foreign exchange market are included as part of explanatory variables besides other fundamentals, using an Error Correction Model (ECM). The use of composite model that incorporates a number of familiar approaches in exchange rate determination is found to outperform the model based on one single approach in term of their forecast performance. The estimation results show that the increase in oil price will depreciate the rupiah exchange rate and that risk factor is the most important factor that influences the rupiah development.
\end{abstract}

JEL Classification: C22, C52, C53, E31, F31, F47

Keywords: Exchange Rate, ECM, composite model, BEER, CEER, forecasting, political risk, economic risk, financial risk. 


\section{PENDAHULUAN}

Studi tentang determinasi nilai tukar sudah banyak dilakukan dan model yang telah dikembangkan untuk menjelaskan perilaku pergerakan nilai tukar pun sudah banyak dikembangkan. Pendekatan yang dilakukan dalam memodelkan nilai tukar pun bervariasi dari model parametrik sampai dengan model non-parametrik. Berbagai model tersebut berusaha menjelaskan perilaku baik nilai tukar nominal maupun nilai tukar riil. Namun demikian, tidak sedikit yang gagal dalam menjelaskan dan memproyeksikan pergerakan nilai tukar ${ }^{1}$.

Di dalam survey yang dilakukan terhadap model empiris nilai tukar, Cheung, Chinn dan Pascual (2003) mengemukakan bahwa salah satu permasalahan yang dihadapi ialah kebanyakan dari model akademis bergantung hanya pada satu model atau konsep dasar, seperti misalnya pada monetary model, atau pada model lain yang berkiprah pada era 1970 seperti misalnya purchasing power parity atau real interest differential model. Hasil survey yang mereka lakukan memperlihatkan bahwa model empiris yang berdasarkan pada beberapa pendekatan atau model dasar, cenderung lebih baik dibandingkan model empiris yang hanya berdasarkan pada satu model atau konsep dasar. Namun mereka juga menemukan bahwa model dan suatu kombinasi mata uang tertentu yang dapat berjalan baik pada suatu periode tidak selalu akan berjalan baik pada periode lain.

Untuk kasus Indonesia telah terdapat beberapa studi empiris dalam model determinasi nilai tukar rupiah terhadap dollar Amerika ${ }^{2}$. Periode sampel pada studi-studi tersebut secara umum mencakup periode krisis nili tukar pada akhir tahun 1997 dan pergantian rezim nilai tukar dari managed floating menjadi free floating. Adanya pergantian rezim nilai tukar ini dapat mempengaruhi hubungan determinasi nilai tukar, sehingga penggunaan variabel dummy untuk menangkap periode krisis belum tentu dapat mengatasi adanya perubahan struktural yang mungkin terjadi yang akan berdampak pada perubahan hubungan determinasi nilai tukar. Hal ini diperkuat oleh hasil studi Cheung,

\footnotetext{
${ }^{1}$ Untuk studi literatur, lihat misalnya Cheung, Chinn dan Pascual (2003), dan Frankel dan Rose (1994), keduanya melakukan survey terhadap model empiris nilai tukar yang pernah dikembangkan.

${ }^{2}$ Lihat misalnya Saxena (2002) untuk periode 1980-1998, Nuryadin dan Santoso (2004) untuk periode 1980-2000, dan Sahminan (2005) untuk periode 1993-2005.
} 
Chinn dan Pascual (2003) tentang sensitifitas pemodelan nilai tukar terhadap periode sampel.

Lebih jauh lagi, adanya perkembangan kondisi perekonomian Indonesia paskakrisis yang memiliki karakterisik yang berbeda dengan pra-krisis, seperti misalnya perubahan peran Indonesia dari net-eksportir minyak menjadi net-importir minyak (grafik 1), dicurigai telah mempengaruhi pergerakan nilai tukar rupiah, terlebih dengan adanya volatilitas harga minyak internasional yang cukup tinggi. ${ }^{3}$ Oleh karena itu, model determinasi nilai tukar yang dapat menangkap perubahan karakteristik ini dapat memberikan gambaran perilaku pergerakan nilia tukar yang lebih tepat.

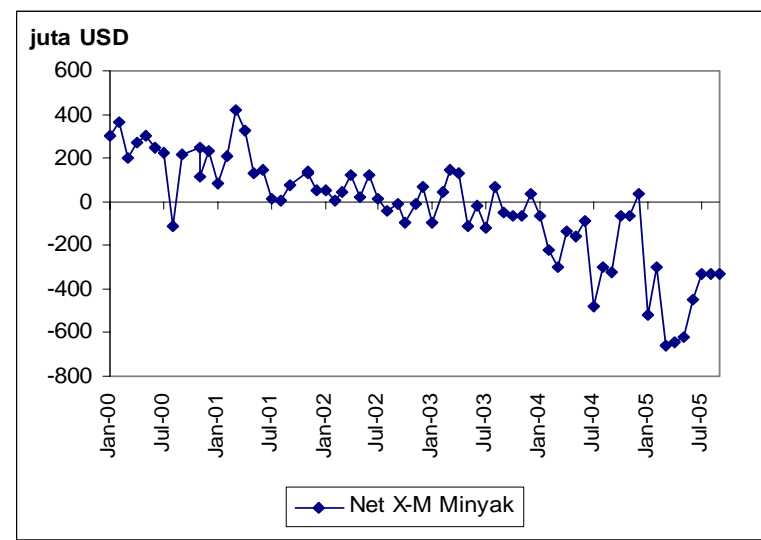

Grafik 1. Net Ekspor-Impor Minyak Indonesia Sumber: Statistik Perminyakan Indonesia - Ditjen Migas, diolah

Sementara itu dari sisi pasar valas, pergerakan nilai tukar rupiah sangat dipengaruhi oleh mekanisme pasar yang merupakan interaksi antara supply dan demand terhadap valas, selain intervensi yang dilakukan oleh bank sentral dalam melaksanakan kebijakan moneternya. Pengaruh interaksi supply dan demand valas tersebut terhadap nilai tukar rupiah terlihat pada grafik 2. di mana pola perkembangan nilai tukar rupiah bergerak searah dengan perkembangan net supply-demand pasar valas. Namun demikian, pergerakan nilai tukar rupiah tidak sepenuhnya identik dengan perkembangan supply-

\footnotetext{
${ }^{3}$ Telah terdapat beberapa studi tentang hubungan harga minyak dengan nilai tukar suatu negara, misalnya Amano dan van Norden (1995) untuk kasus Amerika, dan Akram (2000) untuk kasus Norwegia.
} 
demand valas akibat pasokan dan permintaan vals dapat terjadi tanpa melalui transaksi di pasar valas. Selain itu, pergerakan nilai tukar rupiah juga dipengaruhi oleh berbagai faktor lain seperti faktor fundamental perekonomian, seperti misalnya PDB dan inflasi, faktor pergerakan mata uang regional, dan faktor sentimen pasar.

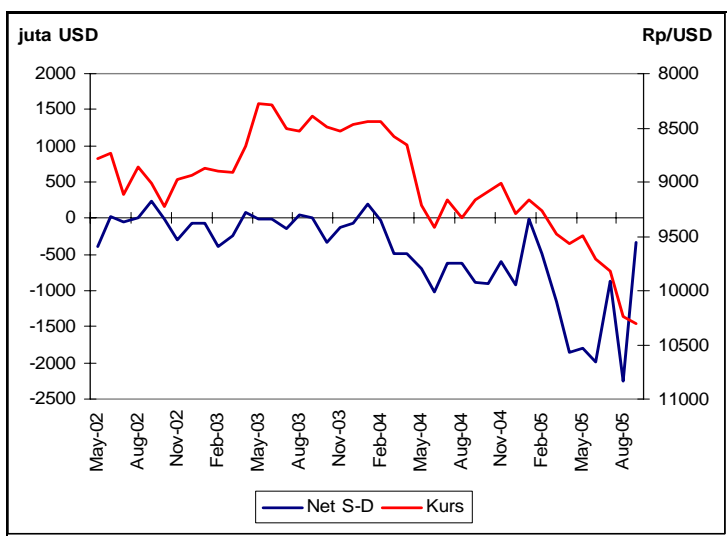

Grafik 2. Nilai Tukar Rupiah dengan Net S-D Valas Total

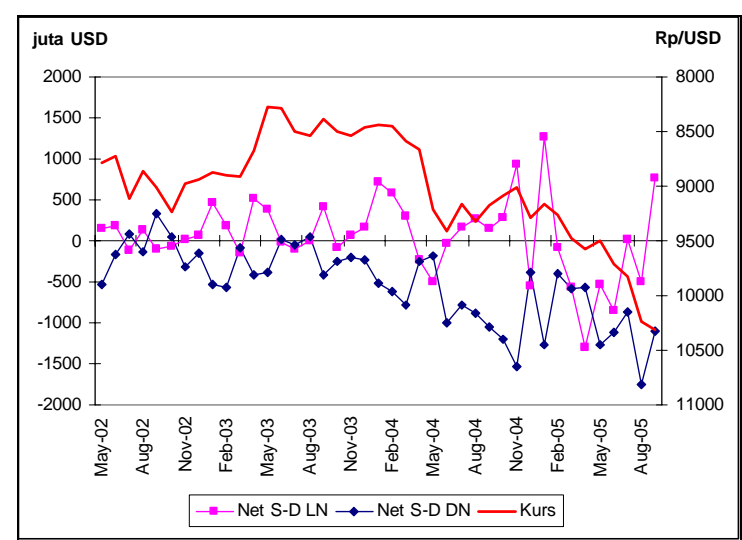

Grafik 3. Nilai Tukar Rupiah dengan Net S-D Valas Menurut Pelaku

Grafik 2. juga memperlihatkan bahwa secara total telah terjadi excess demand untuk pasokan valas yang telah menekan rupiah untuk terdepresiasi. Bila dilihat dari struktur pasar valas domestik pada grafik 3, terlihat bahwa excess demand tersebut terutama bersal dari counterpart bank domestik dari dalam negeri (series Net S-D DN) yang cenderung persisten sebagai net-demander. Sementara itu, counterpart bank domestik dari luar negeri dapat berperan sebagai net-demander maupun net-supplier, yang menggambarkan aliran dana keluar maupun masuk ke dalam negeri. Aliran dana asing ini berfungsi sebagai penyeimbang ekses permintaan valas dari dalam negeri. Peran inilah yang menyebabkan aliran dana asing, atau supply-demand valas dari luar negeri, dapat mempengaruhi pergerakan nilia tukar rupiah. Oleh karena itu, paper ini akan mengkaji pengaruh aliran dana asing dalam determinasi nilai tukar rupiah dengan memasukkan variabel supply-demand valas dari luar negeri sebagai salah satu variabel penjelasnya (explanatory variable).

Berdasarkan beberapa perkembangan tersebut, model determinasi nilai tukar yang dapat menangkap pengaruh faktor-faktor fundamental pasar sesuai kondisi terkini di atas, diharapkan dapat memberikan hasil yang lebih baik dalam memodelkan pergerakan nilai tukar rupiah. Untuk tujuan tersebut, paper ini akan menganalisis penggunaan model 
komposit yang dilandasi oleh beberapa konsep atau model dasar, dan dengan menambahkan variable-variabel yang diduga terkait dengan pergerakan nilai tukar nominal rupiah terhadap dollar Amerika pada periode terkini (paska-krisis).

Bab selanjutnya menjabarkan metodologi dan data yang digunakan dalam penelitian ini. Pada bab tersebut dijelaskan pula pemilihan model nilai tukar yang akan diestimasi. Bab ketiga merupakan analisa empiris yang memuat model empiris yang diestimasi, hasil empiris dan perbandingan kemampuan proyeksi model komposit yang digunakan dengan model lainnya (dalam hal ini dipilih model BEER). Kesimpulan akan diberikan pada bagian akhir. 


\section{METODOLOGI DAN DATA}

\subsection{MODEL NILAI TUKAR}

Model nilai tukar yang digunakan merupakan model komposit yang mewakili beberapa hubungan yang sudah sering digunakan dalam studi determinasi nilai tukar. Model komposit tersebut ialah:

$s_{t}=\beta_{0}+\left(p_{t}-p_{t}^{*}\right)+\beta_{1}\left(i_{t}-i_{t}^{*}\right)+\beta_{2} s d v_{t}+\beta_{3} t o t_{t}+\beta_{4}$ poil $+\beta_{5} r i s k_{t}+u_{t}$

dimana $s$ merupakan log dari nilai tukar nominal rupiah terhadap dollar Amerika, $p-p^{*}$ merupakan price differential, $i-i{ }^{*}$ merupakan nominal interest rate differential, $s d v$ merupakan rasio antara penawaran terhadap permintaan valas dari luar negeri, tot merupakan term of trade, poil merupakan log dari harga minyak internasional, dan risk merupakan log dari indeks risiko yang mencakup political risk, economic risk dan financial risk. Koefisien pada price differential direstriksi bernilai satu (unitary coefficient), atau dengan kata lain diasumsikan bahwa purchasing power parity, PPP, terpenuhi dalam jangka panjang.

Model komposit tersebut menggunakan atribut yang sama dengan model BEER ${ }^{4}$ dalam hal adanya variable risiko dan juga sejalan dengan model CHEER dalam 2 hal, (i) penggunaan asumsi bahwa PPP dapat terpenuhi dalam jangka panjang dan (ii) keberadaan nominal interest rate differential ${ }^{5}$. Model yang merupakan komposit dari beberapa model nilai tukar seperti model komposit ini merupakan pendekatan yang sudah sering digunakan dalam menentukan pergerakan nilia tukar, khususnya dalam konteks perumusan kebijakanl Lihat Cheung, Chinn dan Pascual, (2003).

Model komposit ini memasukkan rasio supply-demand valas dari luar negeri yang menggambarkan transaski valas antara bank domestik dengan counterpart di luar negeri. Selain dapat berfungsi sebagai proksi flow dari net foreign asset (NFA), variable ini juga

\footnotetext{
${ }^{4}$ Lihat Clark dan MacDonald (1999).

${ }^{5}$ Model CHEER berangkat dari asumsi PPP terpenuhi dalam jangka panjang, sehingga dalam jangka pendek nilai tukar dapat terdeviasi dari kondisi jangka panjangnya dengan adanya interest rate differential yang tidak sama dengan nol yang dijelaskan dengan menggunakan konsep UIP. Model ini terbukti lebih baik dari model random walk (McDonald dan Marsh (1997)) bahkan dalam forecast jangka pendek. Lihat MacDonald, 2000.
} 
menggambarkan kondisi pasar valas yang sesungguhnya di mana transaksi valas dengan luar negeri cenderung berfungsi sebagai penyeimbang dari transaksi valas dalam negeri yang pada periode sample cenderung selalu mengalami excess demand (lihat bab Pendahuluan, Grafik 2) sehingga pergerakan nilai tukar rupiah diduga lebih ditentukan oleh transaksi valas dengan luar negeri. Koefisien $\beta_{2}$ akan bernilai positif jika excess demand dari transasksi valas luar negeri, yang ditandai oleh nilai $\beta_{2}<1$, akan menyebabkan depresiasi nilai tukar rupiah, dan jika excess supply, yang ditandai oleh nilai $\beta_{2}>1$, akan menyebabkan apresiasi nilai tukar rupiah.

Variabel harga minyak internasional dimasukkan secara ekplisit ke dalam model meskipun sebenarnya sudah termasuk ke dalam komponen terms of trade. Hal ini dilakukan untuk melihat dampak langsung kenaikan harga minyak terhadap nilai tukar rupiah. Berubahnya peran Indonesia dari net eksportir menjadi net importir sejak akhir tahun 2002 dan besarnya peningkatan harga minyak internasional yang terjadi belakangan ini diduga memiliki pengaruh yang cukup signifikan dalam depresiasi nilai tukar sehingga koefisien $\beta_{3}$ diduga akan bernilai positif.

Koefisien $\beta_{2}$ pada variabel tot tergantung pada besarnya substitution effect dan income effect dari kenaikan harga ekspor impor. Adanya kenaikan harga ekspor akan meningkatkan pendapatan eksportir sehingga terjadi peningkatan supply valas ke dalam negeri akibat meningkatnya devisa hasil ekspor, dalam hal ini dinyatakan sebagai income effect. Namun demikian, kenaikan harga komoditi ekspor dalam negeri yang tidak diikuti oleh kenaikan harga pesaing dari luar negeri untuk komoditi yang sama, akan menurunkan daya saing ekspor dalam negeri yang dapat menyebabkan beralihnya konsumen kepada produk ekspor dari negara pesaing. Hal ini dinyatakan sebagai substitution effect yang akan menurunkan supply valas ke dalam negeri sehingga akan menyebabkan depresiasi nilai tukar. Secara total koefisien $\beta_{2}$ akan bernilai negatif jika income effect lebih besar dari substitution effect, dan sebaliknya akan bernilai positif jika substitution effect lebih besar dari pada income effect.

Untuk mengetahui apakah model komposit ini dapat memberikan proyeksi yang lebih baik dari pada salah satu model dasarnya, dilakukan perbandingan proyeksi model komposit dengan proyeksi berdasarkan model BEER seperti dalam Clark dan MacDonald 
(1999). Model BEER tersebut, yang selanjutnya akan disebut model BEER murni dalam paper ini, ialah:

$q_{t}=\beta_{0}+\beta_{1}\left(r_{t}-r_{t}^{*}\right)+\beta_{2} n f a_{t}+\beta_{3} t_{t o t}+\beta_{4} t n t+\beta_{5} r i s k_{t}+u_{t}$

dimana $q$ merupakan $\log$ dari nilai tukar riil rupiah terhadap dollar Amerika, $r-r^{*}$ merupakan riil interest rate differential, $n f a$ merupakan net foreign asset (NFA), tot merupakan term of trade, tnt merupakan harga relatif barang traded non-traded, dan risk ialah log dari indeks risiko yang mencakup political risk, economic risk dan financial risk.

Kriteria perbandingan kemampuan proyeksi yang digunakan dalam paper ini adalah root mean squared error (RMSE) dan mean absolute error (MAE) untuk proyeksi nilai tukar dalam growth, dan mean absolute percentage error (MAPE) untuk proyeksi nilai tukar dalam level.

\subsection{METODE EKONOMETRIK}

Metode yang akan digunakan ialah metode error correction model (ECM) berdasarkan pertimbangan bahwa nilai tukar dan beberapa explanatory variable merupakan series yang non-stationer yang akan diuji terlebih dahulu dengan uji unit-root. Uji kointegrasi dilakukan dengan metode Engle dan Granger (1987), yaitu dengan menguji stasioneritas kombinasi linier dari variabel-variabel non-stasioner.

Metode ECM yang digunakan untuk mengestimasi persamaan (1) dan (2) ialah sebagai berikut: jika (3) merupakan persamaan jangka panjang, maka (4) merupakan ECM, yang mengestimasi (3) dan (4) secara bersamaan dengan menyelesaikan (2) untuk $u_{t-1}$ dan mensubstitusikannya ke (4):

$y_{t}=\alpha_{0}+\alpha_{1} x_{1 t}+\alpha_{2} x_{2 t}+u_{t}$

$\Delta y_{t}=\beta_{0}+\mu_{t-1}+\sum_{s=0}^{n} \beta_{1} \Delta x_{1 t-s}+\sum_{s=0}^{n} \beta_{2} \Delta x_{2 t-s}+\varepsilon_{t}$

atau 
$\Delta y_{t}=\beta_{0}-\gamma\left(y-\alpha_{0}-\alpha_{1} x_{1}-\alpha_{2} x_{2}\right)_{t-1}+\sum_{s=0}^{n} \beta_{1} \Delta x_{1 t}+\sum_{s=0}^{n} \beta_{2} \Delta x_{2 t}+\varepsilon_{t}$

dengan $\gamma$ yang merupakan speed of adjustment dari variabel dependen ke kondisi jangka panjangnya. Variabel - variabel pada persamaan (3) dinyatakan terkointegrasi jika $u_{t}$ merupakan series yang statsioner dan estimasi $\gamma$ pada (4) memberikan hasil yang signifikan. Selanjutnya forecast untuk nilai $y_{t}$ dilakukan berdasarkan persamaan (4).

\subsection{DATA}

Data yang digunakan merupakan data bulanan periode 2002(5)-2005(9). Pemilihan periode sampel dilakukan berdasarkan pertimbangan keperluan analisis pengaruh harga minyak internasional terhadap nilai tukar rupiah, karena pada akhir 2002 Indonesia mulai menjadi net-importir minyak. Di samping itu ketersediaan data supply demand valas yang baru tersedia semenjak pertengahan April 2002 juga mempengaruhi pemilihan periode sampel.

Untuk memberikan gambaran perilaku dinamik variabel yang akan diestimasi, dilakukan analisa grafik pergerakan series variabel yang diestimasi. Grafik 2 s.d 10 memberikan plot variabel-variabel tersebut.

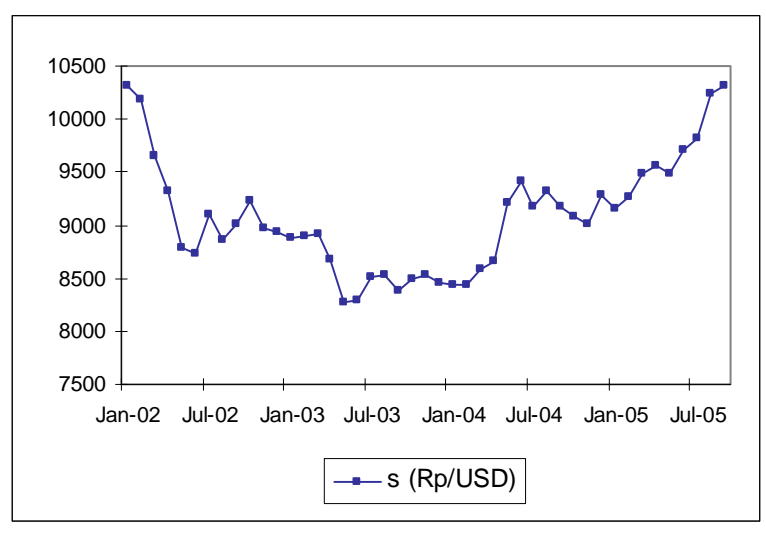

Grafik 3 Plot Nilai Tukar Nominal

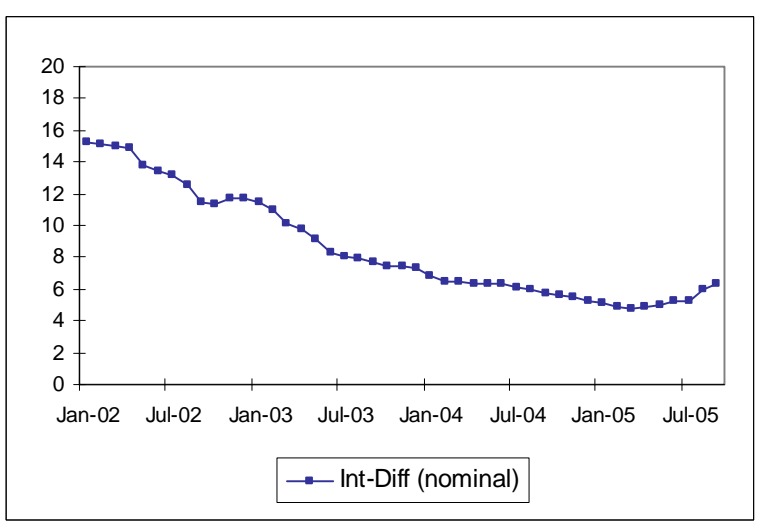

Grafik 4 Plot SBI-FedFund 


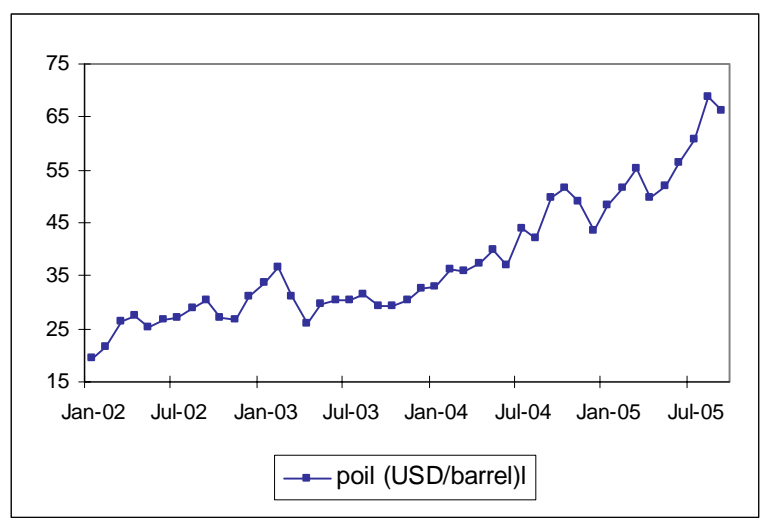

Grafik 5 Plot Harga Minyak

Internasional

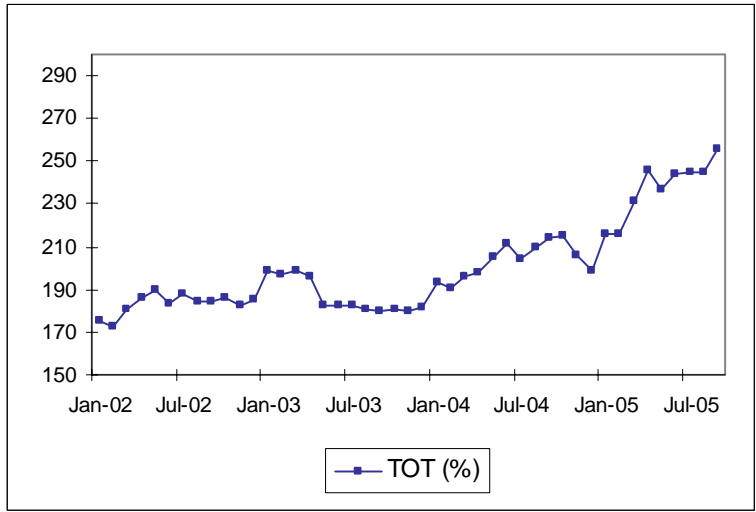

Grafik 7 Plot TOT

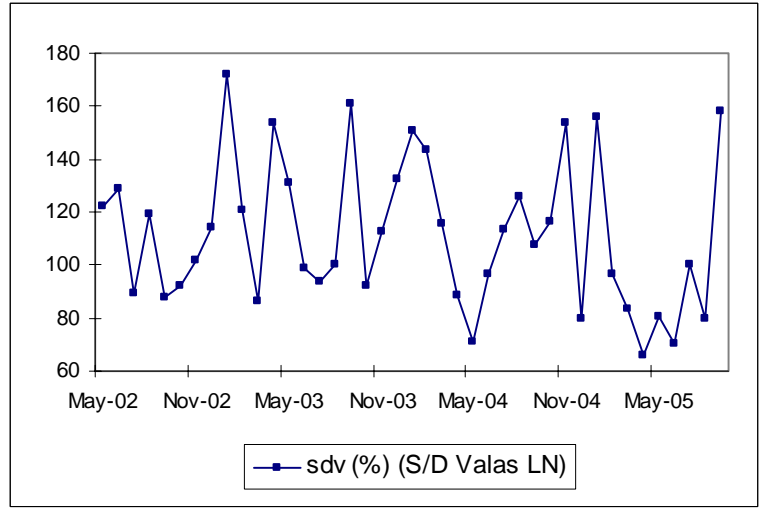

Grafik 9 Plot Rasio S/D Valas

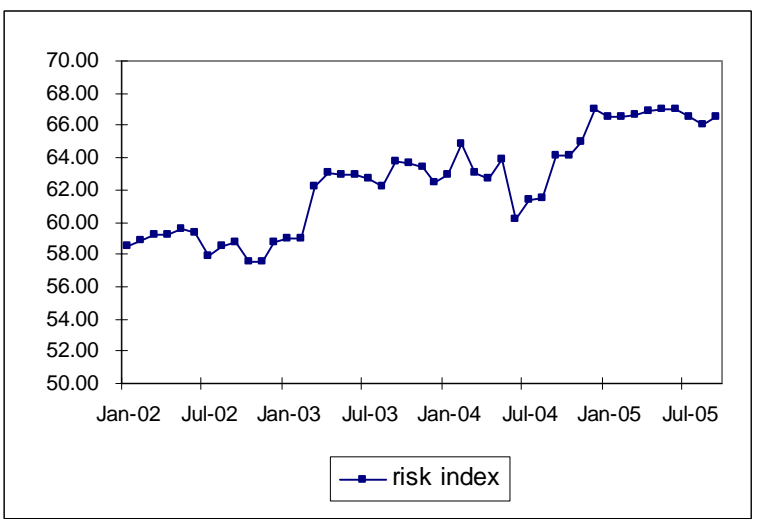

Grafik 6 Plot Indeks Resiko

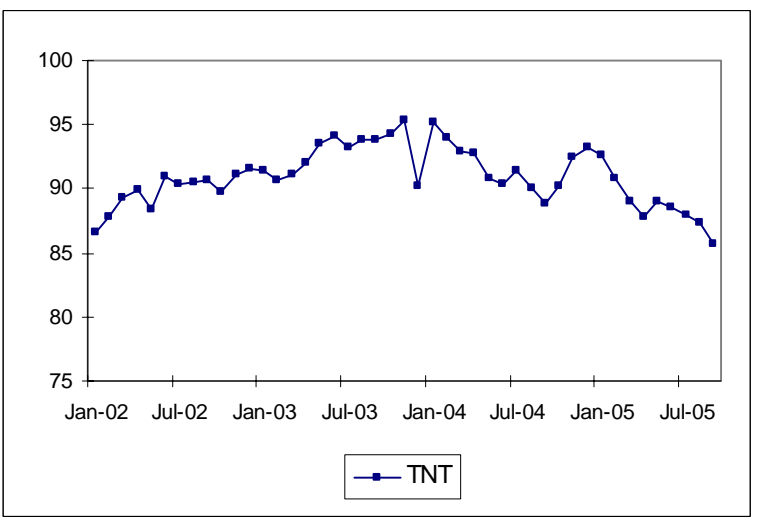

Grafik 8 Plot TNT

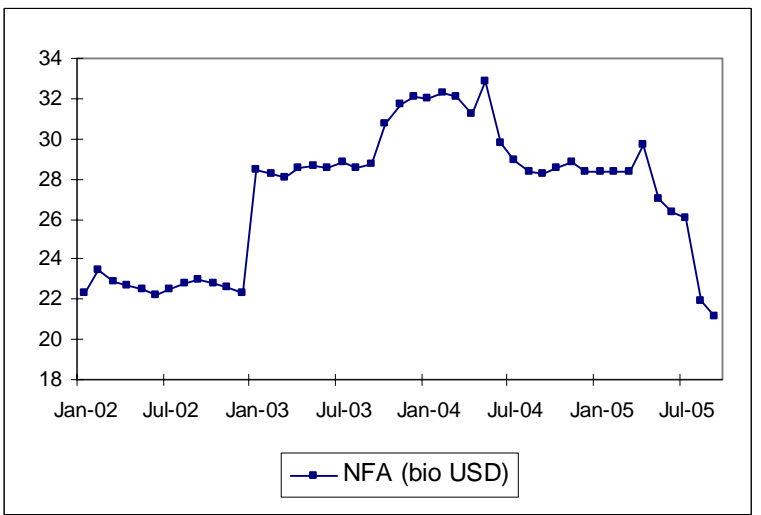

Grafik 10 Plot NFA

\section{Luar Negeri}


Dari kedelapan grafik di atas terlihat bahwa pada umumnya variabel-variabel tersebut memiliki trend jangka panjang kecuali variabel $s d v$ pada Grafik 9. Berdasarkan hal tersebut dapat diduga bahwa hanya $s d v$, yang merupakan rasio supply terhadap demand valas dari lnegeri, yang merupakan variabel stasioner. Variabel $s d v$ ini dibentuk dalam rasio, dengan pertimbangan bentuk net supply-demand akan memberikan nilai negatif. 


\section{ANALISA EMPIRIK}

\subsection{MODEL EMPIRIK}

Model ECM yang diestimasi untuk model komposit ialah:

$$
\begin{aligned}
\Delta s_{t}= & \delta_{0}+\gamma\left(s+p^{*}-p\right)_{t-1}+\delta_{1}\left(i-i^{*}\right)_{t-1}+\delta_{2} s d v_{t-1}+\delta_{3} t t_{t-1}+\delta_{4} \text { poil }_{t-1}+\sum_{s=0}^{n} \beta_{1 s} \Delta s_{t-1-s} \\
& +\sum_{s=0}^{n} \beta_{2 s} \Delta\left(i-i^{*}\right)_{t-s}+\sum_{s=0}^{n} \beta_{3 s} \Delta s d v_{t-s}+\sum_{s=0}^{n} \beta_{4 s} \Delta t o t_{t-s}+\sum_{s=0}^{n} \beta_{5 s} \Delta p o i l_{t-1}+\sum_{s=0}^{n} \beta_{6 s} \Delta r i s k_{t} \\
& +\varepsilon_{t}
\end{aligned}
$$

dimana $\delta_{0}=\beta_{0}-\gamma \alpha_{0}, \delta_{1}=-\gamma \alpha_{1}, \delta_{2}=-\gamma \alpha_{2}, \delta_{3}=-\gamma \alpha_{3}, \delta_{4}=-\gamma \alpha_{4}$ dan $\gamma<0$.

Persamaan (5) merupakan reduced form dari persamaan (6) dan (7) berikut:

$$
s_{t}=\alpha_{0}+\left(p_{t}-p_{t}^{*}\right)+\alpha_{1}\left(i_{t}-i_{t}^{*}\right)+\alpha_{2} s d v_{t}+\alpha_{3} t_{t o t}+\alpha_{4} \text { poil }_{t}+u_{t}
$$

$$
\begin{aligned}
\Delta s_{t}= & \beta_{0}+\sum_{s=0}^{n} \beta_{1 s} \Delta s_{t-1-s}+\sum_{s=0}^{n} \beta_{2 s} \Delta\left(i-i^{*}\right)_{t-s}+\sum_{s=0}^{n} \beta_{3 s} \Delta s d v_{t-s}+\sum_{s=0}^{n} \beta_{4 s} \Delta t o t_{t-s}+\sum_{s=0}^{n} \beta_{5 s} \Delta \text { poil }_{t-1} \\
& +\sum_{s=0}^{n} \beta_{6 s} \Delta r i s k+\mu_{t-1}+\varepsilon_{t}
\end{aligned}
$$

Perhatikan bahwa variabel risk tidak dimasukkan ke dalam persamaan jangka panjang berdasarkan pertimbangan bahwa nilai tukar secara jangka panjang hanya dipengaruhi oleh faktor fundamental. Estimasi dilakukan berdasarkan teknik general to specific dengan membuang variabel yang tidak signifikan. Jumlah lag dari variabel dalam difference yang dimasukkan ke dalam persamaan ialah $\mathrm{n}=6$. Estimasi koefisien $\beta_{1}$ dilakukan untuk menangkap inersia dalam pergerakan nilai tukar. 


\subsection{HASIL EMPIRIS}

Uji unit root untuk variabel pada persamaan nilai tukar model komposit memperlihatkan bahwa nilai tukar nominal rupiah, price differential, harga minyak internasional, terms of trade dan indeks risiko merupakan series yang non-stasioner (Tabel 1), sementara rasio supply demand valas luar negeri dan nominal interest rate differential merupakan series I(0). Untuk itu uji kointegrasi hanya dilakukan pada series non-stasioner ${ }^{6}$.

Tabel 1 Hasil Uji Unit Root

ADF test (lag) berdasarkan AIC

\begin{tabular}{|ccc|}
\hline Variabel & Level $(X)$ & 1st diff. $d(X)$ \\
\hline \hline$s$ & $-2.045112(1)$ & $-5.345502(0)^{\star}$ \\
$p-p^{*}$ & $-1.405768(3)$ & $-5.567529(2)^{\star}$ \\
$i-i^{*}$ & $-2.196485(5)^{\star \star}$ & \\
$s d v$ & $-4.747372(0)^{*}$ & \\
tot & $1.162425(4)$ & $-3.991086(3)^{\star}$ \\
poil & $0.131793(4)$ & $-6.046271(2)^{\star}$ \\
risk & $-1.199041(0)$ & $-7.788819(0)^{\star}$ \\
$e$ & $-1.130251(0)$ & $-5.549078(0)^{\star}$ \\
$r-r^{*}$ & $-0.956819(0)$ & $-3.962822(0)^{\star}$ \\
tnt & $-0.213663(1)$ & $-8.383416(0)^{\star}$ \\
$n f a$ & $-0.666873(3)$ & $-1.611824(2)^{\star \star \star}$ \\
\hline
\end{tabular}

* signifikan pada level $1 \%$

** signifikan pada level $5 \%$

*** signifikan pada level $10 \%$

Uji kointegrasi model komposit dilakukan dengan mengestimasi variabel $s, p-p$, poil dan tot dalam level, seperti pada persamaan (8), kemudian melihat apakah kombinasi linier dari variabel tersebut merupakan proses yang stasioner. Tabel 2 memperlihatkan hasil uji kointegrasi tersebut.

$s_{t}=\beta_{0}+\left(p_{t}-p_{t}^{*}\right)+\beta_{1}$ tot $_{t}+\beta_{2}$ poil $_{t}+u_{t}$

\footnotetext{
${ }^{6}$ Lihat Patterson, Kerry (2000) halaman 334-335.
} 
Tabel 2. Uji Unit Root Komponen Residual Persamaan (8) Null Hypothesis: ECMR8 has a unit root Exogenous: Constant Lag Length: 0 (Automatic based on AIC, MAXLAG=9)

\begin{tabular}{|lrc|}
\hline & t-Statistic & Prob. $^{*}$ \\
\hline \hline Augmented Dickey-Fuller test statistic & -3.87151 & 0.0046 \\
Test critical values: $1 \%$ level & -3.58474 & \\
$5 \%$ level & -2.92814 & \\
$10 \%$ level & -2.60223 & \\
\hline
\end{tabular}

Setelah diketahui bahwa $s$, poil dan tot memiliki hubungan yang terkointegrasi, maka persamaan (4) dapat diestimasi. Hasil yang didapat dari estimasi persamaan (5) dituliskan dalam persamaan (9) berikut (angka dalam kurung menunjukkan t-statistics), sementara hasil uji kointegrasi dan hasil estimasi model BEER murni dapat dilihat pada Apendiks II.

$$
\begin{aligned}
\Delta s_{t}= & 2.263-0.241\left(s+p^{*}-p\right)_{t-1}+0.008\left(i-i^{*}\right)_{t-1}-0.041 s d v_{t}-0.156 \text { tot }_{t}+0.122 \text { poil }_{t} \\
& (4.198)(-3.007) \\
& -0.360 \Delta r i s k_{t}-0.040 \Delta s d v_{t}+0.157 \Delta s_{t-3}+0.048 d u m 504 \\
(-3.824) \quad(-6.509) \quad(2.031) & \quad \text { Adj } \mathrm{R}^{2}=0.753 \quad \text { DW }=1.771
\end{aligned}
$$




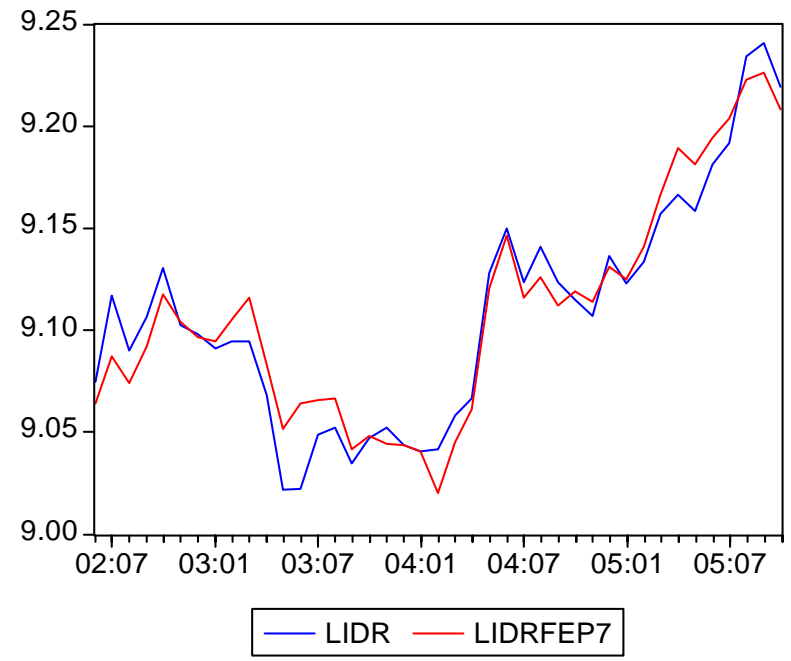

Grafik 11. Plot Level Nilai Tukar Rupiah Aktual (LIDR) v.s

Proyeksi within sample (LIDRFEP7) (dalam log)

Hasil estimasi model komposit memperlihatkan bahwa koefisien pada interest rate differential bernilai positif. Bentuk dari variabel interest rate differential dengan satu lag yang diestimasi langsung dengan depresiasi nilai tukar memiliki bentuk yang sama dengan konsep market arbitrage, khususnya kondisi UIP (Apendiks I). Berdasarkan hal tersebut, hasil estimasi menyatakan bahwa kondisi nominal UIP terpenuhi secara jangka panjang sehingga kenaikan suku bunga dalam negeri relatif terhadap suku bunga luar negeri akan menyebabkan ekspektasi depresiasi. Namun demikian, hasil estimasi memperlihatkan bahwa pengaruh nominal interest rate differential tidaklah kuat, $1 \%$ kenaikan interest rate differential hanya akan menyebabkan $0.008 \%$ depresiasi nilai tukar. Studi empiris sebelumnya berdasarkan data negara yang berbeda-beda yang terkait dengan konsep UIP memperlihatkan hasil yang beragam. Alexius (2001), Meredith dan Chinn (1998) menemukan UIP terpenuhi dalam rentang sample yang panjang, bertolak belakang dengan hasil pada rentang sample yang pendek. MacDonald dan Nagayasu (2000) juga menemukan bahwa long-run interest rate dapat digunakan dalam prediksi level nilai tukar dengan hasil yang baik. Namun di sisi lain, Meese dan Rogoff (1988), dan Campbell dan Clarida (1987) tidak mendapatkan bukti yang cukup untuk mendukung konsep UIP. 
Estimasi koefisien pada variabel tot menunjukkan bahwa pada periode estimasi income effect lebih besar daripada substitution effect sehingga kenaikan harga ekspor relatif terhadap harga impor sebesar 1\% akan menyebabkan apresiasi nilai tukar rupiah sebesar $0.156 \%$. Hasil ini bertolak belakang dengan Sahminan (2005) yang justru menemukan bahwa substitution effect lebih besar dari income effect. Perbedaan mungkin disebabkan oleh perbedaan periode sample estimasi yang dilakukan, dan pada kenyataannya pemodelan nilai tukar sensitif terhadap perubahan periode sample (Cheung, Chinn dan Pascual (2003)). Perbedaan hasil yang bertolak belakang baik untuk variabel tot maupun interest rate differential ini juga dapat disebabkan oleh perbedaan struktur perekonomian pada periode estimasi. Dugaan ini didukung oleh hasil studi Zulverdi dan Santoso (2005) yang menyatakan bahwa terjadi perubahan struktur sistem keuangan yang dimulai pada tahun 2002 dengan meningkatnya peranan pasar keuangan dalam total perekonomian.

Sementara itu dari sisi keseimbangan pasar valas, hasil estimasi memperlihatkan bahwa $1 \%$ kenaikan rasio supply terhadap demand valas dari luar negeri secara jangka panjang maupun jangka pendek akan menyebabkan nilai tukar rupiah terapresiasi sebesar $0.04 \%$. Penurunan harga valas atau apresiasi rupiah ini disebabkan oleh bertambahnya supply valas di pasar valas. Namun demikian, hasil estimasi tersebut juga memperlihatkan bahwa penambahan supply ini tidak merupakan faktor utama dalam determinasi nilai tukar dengan cenderung lemahnya pengaruh variabel $s d v$. Hal ini disebabkan oleh penentuan harga (quoted rate), seringkali tidak berdasarkan transaksi aktual seperti halnya pada perdagangan komoditi sehingga harga tidak dapat ditentukan kondisi supply dan demand saja.

Estimasi koefisien harga minyak internasional memperlihatkan bahwa kenaikan $1 \%$ poil akan menyebabkan nilai tukar terdepresiasi sebesar $0.122 \%$. Hal ini sejalan dengan hipotesa awal sehubungan dengan peran Indonesia sebagai net-importir minyak.

Estimasi pengaruh faktor risiko menyatakan bahwa varaibel risk memiliki pengaruh yang paling besar terhadap pergerakan nilai tukar rupiah jika dibandingkan dengan variabel lainnya, di mana kenaikan indeks risiko sebesar $1 \%$ akan menyebabkan apresiasi nilai tukar sebesar $0.36 \%$. Adanya perbaikan ekspektasi kondisi ekonomi, 
politik dan keuangan yang ditandai dengan meningkatnya indeks risiko, akan membawa sentimen positif pada nilai tukar rupiah. Pada kenyataannya, besarnya ketergantungan determinasi nilai tukar terhadap faktor sentimen atau non-fundamental inilah yang menyebabkan tingginya volatilitas nilai tukar rupiah.

Selain faktor-faktor di atas, pergerakan nilai tukar juga dipengaruhi faktor inersia yang terlihat dari estimasi koefisien pada variabel $\Delta s_{t-i}$. Hasil estimasi memperlihatkan bahwa $1 \%$ depresiasi nilai tukar tiga periode sebelumnya akan mempengaruhi depresiasi periode $t$ sebesar $0.157 \%$.

\section{III.3 Perbandingan Kemampuan Proyeksi}

Kemampuan proyeksi within sample antar kedua model dibandingkan berdasarkan kriteria root mean squared error (RMSE) dan mean absolute error (MAE) untuk proyeksi nilai tukar dalam growth, dan mean absolute percentage error (MAPE) untuk proyeksi nilai tukar dalam level. Untuk formulasi perhitungan ketiga kriteria tersebut, dapat ditemukan pada Apendiks III. Tabel 3 memperlihatkan hasil dari ketiga kriteria tersebut.

Tabel 3. Perbandingan Kemampuan Proyeksi

Periode: 2002(6)-2005(9)

\begin{tabular}{|c|c|c|c|}
\hline \multicolumn{2}{|c|}{ Model Komposit } & \multicolumn{2}{|c|}{ Model BEER } \\
\hline \multicolumn{2}{|c|}{$\begin{array}{c}\text { Level IDR nominal } \\
\text { (LIDR) }\end{array}$} & \multicolumn{2}{|c|}{$\begin{array}{l}\text { Level IDR riil } \\
\text { (LRIDR) }\end{array}$} \\
\hline RMSE & 0.010401 & RMSE & 0.019324 \\
\hline MAE & 0.008279 & MAE & 0.015178 \\
\hline \multicolumn{2}{|c|}{$\begin{array}{c}\text { Growth IDR nominal } \\
\text { D(LIDR) }\end{array}$} & \multicolumn{2}{|c|}{$\begin{array}{c}\text { Growth IDR riil } \\
\text { D(LRIDR) }\end{array}$} \\
\hline MAPE & 0.130235 & MAPE & 0.152902 \\
\hline
\end{tabular}

Berdasarkan ketiga kriteria tersebut, dapat dinyatakan bahwa model komposit memiliki kemampuan proyeksi yang lebih baik jika dibandingkan dengan model BEER murni. Nilai RMSE maupun nilai MAE dari proyeksi level nilai tukar model komposit 
lebih kecil jika dibandingkan dengan model BEER murni, begitu juga halnya dengan nilai MAPE pada proyeksi pertumbuhan/pergerakan nilai tukar rupiah. 


\section{KESIMPULAN DAN SARAN}

Perkembangan nilai tukar rupiah paska-krisis memiliki karakterisitk yang berbeda denagn pra-krisis, terutama dengan adanya pergantian rezim nilai tukar dari managed floating ke free floating. Berubahnya peran Indonesia dari net-eksportir minyak menjadi net-importir minyak dan tingginya harga minyak internasional telah membawa tekanan depresiasi terhadap nilai tukar rupiah. Di samping itu perkembangan interaksi supply-demand valas di pasar valas domestik juga memiliki peran yang kuat dalam penentuan pergerakan nilai tukar rupiah.

Estimasi model komposit terhadap nilai tukar rupiah nominal yang menggunakan beberapa konsep dasar dalam determinasi nilai tukar memperlihatkan bahwa kondisi nominal UIP terpenuhi dalam jangka panjang. Variabel harga minyak internasional secara empiris memiliki hubungan positif dengan depresiasi nilai tukar rupiah. Interaksi supplydemand valas yang diwakili oleh variabel rasio supply-demand valas dari luar negeri memiliki hubungan negatif dengan depresiasi nilai tukar rupiah, sehingga kenaikan netsupply valas dari luar negeri dapat menyebabkan apresiasi nilai tukar rupiah. Dari sisi harga relatif ekspor terhadap impor, secara total income effect lebih besar dari pada substitution effect sehingga kenaikan terms of trade akan menyebabkan nilai tukar rupiah terapresiasi. Namun demikian, variabel risiko merupakan variabel yang memiliki pengaruh terbesar dalam penentuan pergerakan nilai tukar rupiah.

Dari sisi pemodelan, penggunaan model komposit lebih baik jika dibandingkan dengan model BEER murni. Hal ini berdasarkan pertimbangan kemampuan proyeksi yang dilihat dari kriteria RMSE, MAE dan MAPE pada proyeksi dalam periode sampel.

Untuk pengembangan selanjutnya, dibutuhkan studi yang dapat menjelaskan determinan aliran dana asing atau supply-demand valas dari luar negeri secara menyeluruh. 


\section{DAFTAR PUSTAKA}

Alexius, Annika (2001),'Uncovered Interest Rate Parity Revisited”, Review of International Economics, Vol.9, pp 505-517.

Campbell, John dan Clarida, R. (1987),'The dollar and Real Interest Rate", CarniegeRochester Conference on Public Policy 27.

Cheung, Yin-Wong, Chinn, Menzie D., dan Pascual, Antonio Garcia (2003),'Empirical Exchange Rate Models of the Nineties: Are Any Fit to Survive?", NBER Working Paper, no. 9393.

Clark, P. B. dan MacDonald, R. (1999),'Exchange Rates and Economic Fundamentals: a Metodological Comparisons of BEERs and FEERs", dalam MacDonald, R. dan Stein, J., eds., Equilibrium Exchange Rates, Kluwer Academic Publishers.

MacDonald, R. (2000),"Concepts to Calculate Equilibrium Exchange Rate: an Overview", Economics Research Group of the Deutsche Bundesbank, Discussion Paper 3/00.

MacDonald, R. dan Marsh, I. W. (1997),’On Casselian PPP, Cointegration and Exchange Rate Forecasting”, Review of Economics and Statistics, Vol. LXXXIX, pp- 655-64.

MacDonald, R. dan Nagayasu, J. (2000),'The Long-Run Rleationship between Real Exchange Rates and Real Interest Rate Differentials," IMF Staff Papers, no. 47, pp 116-128.

Meese, R. dan Rogoff, K. (1988),'Was It Real? The Exchange Rate Interest Rate Differential Relation over the Modern Floating-Rate Period," Journal of Finance, no. 43 , pp 933-47.

Meredith, G. dan Chinn, M. (1998),'Long Horizon Uncovered Interest Rate Parity”, NBER Working Paper, no. 6797.

Nuryadin, Didi dan Santoso, Bagus (2004),"Analisis Aplikasi Model Neraca Pembayaran dan Moneter Terhadap Nilai Tukar Rupiah/Dolar, Periode 1980.1-2000.4”, Buletin Ekonomi Moneter dan Perbankan, Bank Indonesia, Vol. 7, no. 2. 
Sahminan (2005),"Estimating the Equilibrium Real Exchange Rate of the Rupiah", Economics Research Bureau, Bank Indonesia, mimeo.

Saxena, Sweta C. (2002),"Exchange Rate Dynamics in Indonesia”, Journal of Asian Economics, Vol. 13, pp 545-63.

Zulverdi, Doddy dan Santoso, M. Setyawan (2005),’Dampak Perubahan Struktur Sistem Keuangan terhadap Transmisi kebijakan Moneter di Indonesia”, Directorat Riset Ekonomi dan Kebijakan Moneter, mimeo. 


\section{APENDIKS I}

Kondisi uncovered interest rate parity (UIP) menyatakan bahwa kenaikan perbedaan suku bunga dalam dan luar negeri akan menyebabkan ekspektasi depresiasi sehingga investor akan menjadi indifferent antara aset domestik dengan aset luar negeri dengan tambahan suatu premi risiko tertentu. Hubungan ini dapat digambarkan dengan persamaan berikut:

$s_{t}=E s_{t+1}+i_{t}-i_{t}^{*}+\sigma_{t}$

di mana $s$ ialah log dari nilai tukar nominal, $i$ dan $i^{*}$ mewakili suku bunga nominal dalam dan luar negeri, dan $\sigma$ merupakan premi risiko yang nilainya dapat bervariasi terhadap waktu.

Dengan asumsi rational expectation, persamaan (i) dapat ditulis dalam bentuk berikut:

$$
\Delta s_{t+1}=i_{t}-i_{t}^{*}+\sigma_{t}
$$

atau jika dalam lag satu dan mengeluarkan premi risiko:

$$
\Delta s_{t}=i_{t-1}-i_{t-1}^{*}
$$

Persamaan (iii) merupakan strict form dari bentuk dalam persamaan (9). 


\section{APENDIKS II}

\section{Hasil Estimasi Model Komposit}

Dependent Variable: D(LIDR)

Method: Least Squares

Sample(adjusted): 2002:06 2005:10

Included observations: 41 after adjusting endpoints

\begin{tabular}{crlrr}
\hline \hline Variable & Coefficient & Std. Error & t-Statistic & Prob. \\
\hline \hline C & 2.263482 & 0.539175 & 4.198045 & 0.0002 \\
LIDR(-1)-RPDIFF(-1) & -0.241309 & 0.080250 & -3.006958 & 0.0052 \\
INTDIFF(-1) & 0.008107 & 0.001897 & 4.274135 & 0.0002 \\
PSDLN(-1) & -0.041130 & 0.008879 & -4.632345 & 0.0001 \\
LTOT(-1) & -0.156084 & 0.047357 & -3.295920 & 0.0025 \\
LPOIL(-1) & 0.121540 & 0.020068 & 6.056386 & 0.0000 \\
D(LRISK) & -0.359816 & 0.094094 & -3.824009 & 0.0006 \\
D(PSDLN) & -0.039946 & 0.006137 & -6.508990 & 0.0000 \\
D(LIDR(-3)) & 0.156617 & 0.077097 & 2.031438 & 0.0509 \\
DUM504 & 0.048024 & 0.011696 & 4.105932 & 0.0003 \\
\hline \hline R-squared & 0.808297 & Mean dependent var & 0.003378 \\
Adjusted R-squared & 0.752641 & S.D. dependent var & 0.021668 \\
S.E. of regression & 0.010776 & Akaike info criterion & -6.014688 \\
Sum squared resid & 0.003600 & Schwarz criterion & -5.596744 \\
Log likelihood & 133.3011 & F-statistic & & 14.52317 \\
Durbin-Watson stat & 1.770947 & Prob(F-statistic) & & 0.000000 \\
\hline \hline
\end{tabular}

\section{Hasil Estimasi Model BEER Murni}

Dependent Variable: D(LRIDR)

Method: Least Squares

Sample(adjusted): 2002:06 2005:10

Included observations: 41 after adjusting endpoints

\begin{tabular}{crlrr}
\hline \hline Variable & Coefficient & Std. Error & t-Statistic & Prob. \\
\hline C & 9.166371 & 2.722751 & 3.366585 & 0.0023 \\
LRIDR(-1) & -0.945613 & 0.200149 & -4.724548 & 0.0001 \\
RINTDIFF(-1) & -0.007439 & 0.003008 & -2.473133 & 0.0200 \\
LTOT(-1) & 0.281054 & 0.091113 & 3.084668 & 0.0047 \\
LNFA(-1) & -0.195239 & 0.062266 & -3.135560 & 0.0041 \\
LRISK(-1) & -0.913108 & 0.200857 & -4.546060 & 0.0001 \\
LTNT(-1) & 0.267443 & 0.271442 & 0.985267 & 0.3332 \\
D(LRISK) & -0.732714 & 0.177681 & -4.123768 & 0.0003 \\
D(LNFA(-1)) & 0.078687 & 0.072948 & 1.078666 & 0.2903 \\
D(RINTDIFF(-2)) & 0.009373 & 0.004178 & 2.243662 & 0.0333 \\
D(LRIDR(-1)) & 0.356352 & 0.145782 & 2.444411 & 0.0213 \\
D(LTOT(-1)) & -0.197069 & 0.105762 & -1.863317 & 0.0733 \\
D(LTNT(-4)) & 0.303553 & 0.197709 & 1.535349 & 0.1363 \\
DUM504 & 0.036211 & 0.021242 & 1.704704 & 0.0997 \\
\hline \hline R-squared & 0.665880 & Mean dependent var & -0.000611 \\
Adjusted R-squared & 0.505007 & S.D. dependent var & 0.023595 \\
S.E. of regression & 0.016601 & Akaike info criterion & -5.093560 \\
Sum squared resid & 0.007441 & Schwarz criterion & & -4.508438 \\
Log likelihood & 118.4180 & F-statistic & & 4.139173 \\
Durbin-Watson stat & 2.242663 & Prob(F-statistic) & & 0.000892 \\
\hline \hline
\end{tabular}




\section{APENDIKS III}

Misalnya sampel proyeksi adalah $j=T+1, T+2, \ldots, T+h$, nilai aktual adalah $y_{t}$, dan nilai proyeksi adalah $\hat{y}_{t}$. Maka statistik kesalahan proyeksi adalah sebagai berikut:

Root Mean Squared Error: $\sqrt{\sum_{t=T+1}^{T+h}\left(\hat{y}_{t}-y_{t}\right)^{2} / h}$

Mean Absolute Error: $\sum_{t=T+1}^{T+h}\left|\hat{y}_{t}-y_{t}\right| / h$

Mean Absolute Percentage Error: $100 \sum_{t=T+1}^{T+h}\left|\frac{\hat{y}_{t}-y_{t}}{y_{t}}\right| / h$ 